\title{
Determinants of satisfaction with campus transportation services: Implications for service quality

\begin{tabular}{|c|c|}
\hline $\begin{array}{l}\text { Authors: } \\
\text { Felix Charbatz } \\
\text { Udechukwu O } \\
\text { Maxwell Chip } \\
\text { Alasdair Mars }\end{array}$ & $\begin{array}{l}\text { adeh }^{1} \\
\text { jiako }^{2,3} \\
\text { llu }^{1,4} \\
\text { nall }^{1}\end{array}$ \\
\hline $\begin{array}{l}\text { Affiliations: } \\
{ }^{1} \text { Southamptor } \\
\text { School, Unive } \\
\text { Southampton } \\
\text { Kingdom }\end{array}$ & $\begin{array}{l}\text { Business } \\
\text { sity of } \\
\text { United }\end{array}$ \\
\hline $\begin{array}{l}{ }^{2} \text { Faculty of Bu } \\
\text { British Univers } \\
\text { United Arab E }\end{array}$ & $\begin{array}{l}\text { iness \& Law, } \\
\text { ity in Dubai, } \\
\text { mirates }\end{array}$ \\
\hline $\begin{array}{l}{ }^{3} \text { Hull Universit } \\
\text { School, Unive } \\
\text { United Arab E }\end{array}$ & $\begin{array}{l}\text { y Business } \\
\text { sity of Hull, } \\
\text { nirates }\end{array}$ \\
\hline $\begin{array}{l}{ }^{4} \text { Faculty of Ma } \\
\text { University of J } \\
\text { South Africa }\end{array}$ & $\begin{array}{l}\text { nagement, } \\
\text { ohannesburg, }\end{array}$ \\
\hline $\begin{array}{l}\text { Correspondin } \\
\text { Udechukwu O } \\
\text { udechukwu.oj } \\
\text { com }\end{array}$ & $\begin{array}{l}\text { author: } \\
\text { jiako, } \\
\text { iako@outlook. }\end{array}$ \\
\hline $\begin{array}{l}\text { Dates: } \\
\text { Received: } 20 \mathrm{~J} \\
\text { Accepted: } 26 \\
\text { Published: } 28\end{array}$ & $\begin{array}{l}\text { uly } 2015 \\
\text { Oct. } 2015 \\
\text { Apr. } 2016\end{array}$ \\
\hline $\begin{array}{l}\text { How to cite th } \\
\text { Charbatzadeh } \\
\text { Chipulu, M. \& } \\
\text { 2016, 'Determ } \\
\text { satisfaction w } \\
\text { transportation } \\
\text { Implications fc } \\
\text { quality', Journ } \\
\text { and Supply Ch } \\
\text { Management } \\
\text { http://dx.doi. } \\
\text { jtscm.v10i1.2C }\end{array}$ & $\begin{array}{l}\text { is article: } \\
\text { F., Ojiako, U., } \\
\text { Marshall, A., } \\
\text { inants of } \\
\text { th campus } \\
\text { services: } \\
\text { r service } \\
\text { al of Transport } \\
\text { ain } \\
10(1) \text {, a203. } \\
\text { rg/10.4102/ } \\
3\end{array}$ \\
\hline $\begin{array}{l}\text { Copyright: } \\
\text { C 2016. The A } \\
\text { Licensee: AOS } \\
\text { is licensed unc } \\
\text { Creative Comr } \\
\text { Attribution Lic }\end{array}$ & $\begin{array}{l}\text { uthors. } \\
\text { S. This work } \\
\text { ler the } \\
\text { nons } \\
\text { ense. }\end{array}$ \\
\hline Read online: & \\
\hline 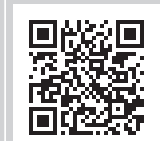 & $\begin{array}{l}\text { Scan this QR } \\
\text { code with your } \\
\text { smart phone or } \\
\text { mobile device } \\
\text { to read online. }\end{array}$ \\
\hline
\end{tabular}

Background: In a number of countries, buses are a critical element of public transportation, providing the most inclusive and sustainable mode of transportation to all forms of citizenry, including staff and students of universities.

Objectives: The study examines the determinants of satisfaction with campus bus transportation. The article is primarily discursive and based on the synthesis of existing service literature supported by data obtained from a survey of 847 respondents.

Method: Structural equation modelling is undertaken using AMOS 19, allowing for the examination of compound relationships between service engagement variables.

Results: Results show statistically significant differences between perceived service quality and travel routes. The authors argue that managerial attention to service user experiences does not only hold the key to ongoing competitive success in campus transportation services but also that those services can be significantly enriched through greater managerial attention to the interface between risk of financial loss (which increases when the campus bus transportation service provider becomes less able to compete) and service quality.

Conclusion: The authors argue that if providers of campus bus transportation services are to rise to their service delivery challenges and also maintain or improve upon their market positions, they must conceptualise their services in a manner that takes into consideration the two-way interrelationship between risk of financial loss and service quality. It must also be noted that, although this study may have relevance for firm-firm scenarios, its focus is primarily on service supplier firm-customer service engagements.

\section{Introduction}

\section{Overview}

Scholars have long been concerned with the question of how service may be a key driver for a service supplier firm's prosperity and survival (Busse \& Wallenburg 2011; Daugherty, Chen \& Ferrin 2011; Grawe, Autry \& Daugherty et al. 2014). As shown in the wide range of research available (see Busse \& Wallenburg 2011; Bustinza, Parry \& Vendrell-Herrero 2013; Grawe 2009; Hsu 2013; Kahkonen, Lintukangas \& Hallikas 2015; Lin, Pekkarinen \& Ma 2015; Yazdanparast, Manuj \& Swartz 2010), the topic of service is important in logistics research. Service is also recognised as having an influence on customer behaviour (Pedrosa, Blazevic \& Jasmand 2015; Tokar 2010; Su, Ke \& Cui 2014); hence, it is of no surprise that scholars who have set out to establish an agenda for both service (Chandler \& Lusch 2015; Ostrom et al. 2015) and logistics research (Bonney \& Jaber 2014; Busse \& Wallenburg 2011; Daugherty 2011; Defee et al. 2011; Connelly, Ketchen \& Hult 2013; Gonzalez-Loureiro, Dabic \& Kiessling 2015; Olhager, Pashaei \& Sternberg 2015; Weele \& Raaij 2014) have directed considerable attention to the notion of 'service'.

Scholars have long been interested in the question of not only the selection of modes of transport service (Bhattacharya et al. 2014; Correia \& Antunes 2012; Jain et al. 2014), but also in customer service quality and supplier-customer relationship satisfaction specific to buses as a mode of transportation (see de Ona et al. 2013; Dell'Olio, Ibeas \& Cecin 2010; Hensher 2014; Hensher, Stopher \& Bullock 2003; Hu \& Jen 2006; Wall \& McDonald 2007; Yang, Kong \& Meng 2001). More specific interest in campus bus transportation can be found in the works of Farzaneh et al. (2009) and Eboli, Mazzulla and Salandria (2013). For example, following the discovery that key challenges still existed in the identification of how bus customers assessed satisfaction with service levels, Hensher et al. (2003) suggested the need to quantify service quality levels as a means of comparing service levels within and between bus operators. Hensher and colleagues' work was followed 
shortly by that of $\mathrm{Hu}$ and Jen (2006) who, on examining bus service quality in Taiwan, found that customers articulated service quality not only with reference to the perceived respect and care they receive from service providers but also in terms of levels of comfort with bus facilities. In other studies, whilst Wall and McDonald (2007) established a relationship between bus frequency and customer satisfaction, Yang et al. (2001) examined how 'value-of-time' distributions were impacted by service diversity and price competition in bus services. In addition, Dell'Olio et al. (2010) examined how quality perceptions of bus service provision varied with levels of information, particularly when new information was made available to customers.

Within this context, two research questions are examined in this study: (1) What service attributes significantly influence the satisfaction of students using campus bus services? and (2) Does customer satisfaction vary depending on bus transport route and frequency? In answering these two questions, the authors seek to make a contribution to knowledge on the imperatives impacting upon user transport mode preferences.

\section{Customer satisfaction and its attributes}

Whilst Engel and Blackwell (1982:501) conceptualise satisfaction as 'an evaluation that the chosen alternative is consistent with prior beliefs with respect to that alternative', Andreassen (1995:33) suggests that customer satisfaction represents 'the accumulated experience of a customer's purchase and consumption experiences' and the performance that is perceived is related to 'the consumer's perception of quality, marketing mix, brand name and image of the company'. It is therefore of no surprise that, because of an interest amongst firms to increase their rate of customer retention, interest in understanding how service components influence customer satisfaction continues to grow following seminal work by Slater (1997), who sought to develop a customer valuebased theory of the firm that 'maximises the effectiveness of the firm's customer value creation activities' (p. 165). Underpinning our understanding of customer satisfaction is the expectancy-disconfirmation theory first introduced by Oliver (1981). According to scholars (e.g. Aurier and Guintcheva 2014; Sengupta, Balaji \& Krishnan 2015), the expectancy-disconfirmation theory posits that customers form a perspective of satisfaction against a specific service and that this is carried out mainly subjectively by comparing their idiosyncratic preferences and ideal expectations. In other words, customer satisfaction remains a psychological construct of expectations and perceptions.

Articulation of the satisfaction construct remains complex not only because of the intricate nature of the interrelationships that exist between assessment attributes which represent the general evaluative criteria for assessing the quality of service employed in judging satisfaction but also because of situational differences that may arise from customers' perceptions of 'quality' (Calabrese \& Scoglio 2012; Dagger \& Sweeney 2007; Parasuraman, Zeithaml \& Malhotra 2005; Zayer, Otnes \& Fischer 2014). Thus, perceptions of service quality may influence customer satisfaction (Burton, Sheather \& Roberts 2003; Dagger \& Sweeney 2007; Nyffenegger et al. 2014; Sureshchandar, Rajendran \& Anantharaman 2002). In other words, quality - which refers to the totality of the characteristics of a service (Golder, Mitra \& Moorman 2012) remains a key factor for researchers seeking to understand consumer satisfaction judgements. These notions of service, quality and customer satisfaction also apply to transportation (Ettema et al. 2011; Weinstein 2000).

A review of literature (see, e.g. De Ona \& De Ona 2015; Eboli \& Mazzulla 2011; Fellesson \& Friman 2012; Morris \& Guerra 2014; Olsson et al. 2012) shows that numerous studies dealing with customer satisfaction in public transportation have been undertaken. Studies specific to bus transport services include that of Hensher et al. (2003), who, following the discovery that key challenges still existed in the identification of how bus customers assessed satisfaction with service levels, suggested the need to quantify service quality levels as a means of comparing service levels within and between bus operators.

Other studies include that of Stradling et al. (2007) that examined the customer experience of the ideal bus journey. As part of the study, they examined the influence of factors such as gender, age and frequency of bus use on the experience of bus users. In another study, Gatersleben and Uzzell (2007) examined affective experiences of daily bus commuters, finding that public transport users generally perceived their experiences as unpleasant. This negative affect was generally seen to be driven by a number of factors such as stress associated with waiting times and delays. In response to similar findings on the negative impact of waiting times on the experience of bus customers, scholars such as Dell'Olio et al. (2010), Politis et al. (2010) and Tang and Thakuriah (2012) have examined the role of real-time bus information systems on improving the overall bus transport experience. Fellesson and Friman (2012), for example, found four satisfaction dimensions - system, comfort, staff, and safety - to be of importance in their assessment of perceived satisfaction with public transport service across nine European cities. At the same time, the findings from the studies by Gatersleben and Uzzell are not surprising in view of much earlier work by Van Vugt, Van Lange and Meertens (1996) into motivational factors underlying the decisions by passengers on whether to commute by car or by public transportation. Van Vugt et al. (1996) had found that commuters preferred journeys that involved not only shorter travel time but also alternative and direct travel routes (Stradling et al. 2007). The question of routing is particularly important, noting the findings of earlier studies. Numerous studies (Broome et al. 2012; Kepaptsoglou \& Karlaftis 2009; Van Oudheusden, Ranjithan \& Singh 1987; Wirasinghe \& Vandebona 2011) all show that optimised bus route designs have the ability to simultaneously enhance customer satisfaction with bus service operations. 
An interesting strand of work that has begun to emerge in transportation studies deals with customer satisfaction as relates to 'mood and mode'. These studies which include, for example, the works of Choi, Coughlin and D'Ambrosio (2012), De Vos et al. (2013), Morris (2013) and Morris and Guerra (2014) have focused on exploring the relationship between satisfaction, access to transportation and travel behaviour. The findings of these studies, whilst not statistically significant, suggest that although individual preference is a major determinant of mode of transportation, a relationship does exist between customer mood and their chosen or preferred mode of transportation. Generally, bus (and train) passengers have been found to have the most negative emotions whilst bicyclists have the most positive emotions. At the same time, there appears to be a relationship between travel behaviour (in terms of the actual commuting experience) and mood, with some scholars such as Choi et al. (2012) and Morris (2013) finding that passengers with longer distances to commute tend to have low levels of satisfaction with their travel experience.

More pertinent to our study, Wall and McDonald (2007) and Wall et al. (2008) had identified the key determinants of satisfaction with bus travel to include frequency, reliability, bus information, comfort of travel, friendliness of bus driver, competence of bus driver, appearance of bus shelters or stops, cleanliness, cost, route, time of travel and sociodemographic factors. In addition, Eboli and Mazulla (2007) had sought to rate customer satisfaction with bus campus services against 16 service quality attributes (see Table 1). In the process, they found three over-arching attributes - (1) planning and reliability, (2) comfort and other factors and (3) network design - as factors impacting customer satisfaction with campus bus services. Similarly, in an extensive study, which involved international comparisons of satisfaction with public transportation experiences, Fellesson and Friman (2012) found four key attributes - (1) systems, (2) information, (3) design and (4) skills - which all seemed capable of significantly impacting the service experiences of public sector transport users.

\section{TABLE 1: Service quality attributes.}

\begin{tabular}{|c|c|}
\hline Attribute & Description \\
\hline Bus stop availability & Availability \\
\hline Route characteristics & $\begin{array}{l}\text { Route characteristics (number of bus stops, } \\
\text { distance between bus stops, etc.) }\end{array}$ \\
\hline Frequency & Service frequency \\
\hline Reliability & Number of buses that arrive on schedule \\
\hline Bus stop furniture & Availability of shelter and benches at bus stops \\
\hline Overcrowding & Bus overcrowding \\
\hline Cleanliness & Cleanliness of interior, seats and windows \\
\hline Cost & Cost affordability \\
\hline Information & Availability of schedule or maps at bus stops \\
\hline Promotion & $\begin{array}{l}\text { Availability of service information by phone, } \\
\text { mail, internet, etc. }\end{array}$ \\
\hline Safety on board & Vehicle reliability and competence of drivers \\
\hline Personal security & Safety against crimes on buses \\
\hline Personnel & Helpfulness of personnel \\
\hline Complaints & Administration of complaints \\
\hline Environmental protection & Use of ecological vehicles \\
\hline Bus stop maintenance & Physical condition of bus stops \\
\hline
\end{tabular}

\section{The study \\ Buses and student transportation}

Buses are a critical element of public transportation. In most countries, buses provide the most inclusive sources of sustainable mode of transportation to all forms of citizenry. Therefore, buses can be regarded as a cornerstone of any nation's social fabric. According to scholars such as Morris, Ison and Enoch (2005), Andaleeb, Haq and Ahmaed (2007) and Ahn (2009), the importance of buses cannot be underestimated when compared to other forms of transportation. For example, buses transport the largest number of passengers within most cities (White 2010). Nevertheless, because studies (Dell'Olio et al. 2010; Eboli \& Mazzulla 2007; Hu \& Jen 2006; Sheth, Triantis \& Teodorovic 2007; Stradling et al. 2007) suggest that bus services face reliability questions, a substantial number of scholars (Chen, Yan \& Tseng 2010; Gu et al. 2011; Sheth et al. 2007) have focused on optimising bus service operations. This is to be expected when one notes that buses share road infrastructure with other motorists.

Compared with many other social groups, students are represented disproportionately as bus transport customers (Limanond, Butsingkorn \& Chermkhunthod 2011; Park \& Kim 2010; Ubillosa \& Sainz 2004). Unsurprisingly, senior administrators across a substantial number of higher institutions promote the use of buses as a sustainable means of transportation with the capacity, if optimised, to enhance overall student experience (Balsas 2006; Bond \& Steiner 2006; Conway et al. 2008). Other institutions have gone further to initiate transportation demand management initiatives that include, for example, the provision of campus bus services. However, these initiatives face considerable challenges for a number of reasons, including (1) an increasing student population which will continue to exert pressure on services, (2) an increase in student wealth (and by implication, students who have enough disposable income to purchase cars; see Bamberg and Schmidt 2003), (3) a general student preference for car travel over the utilisation of public transport services (Eriksson, Friman \& Garling 2013; Paez \& Whalen 2010) and (4) the existence of studies showing that students tend to make mode of transportation selection decisions based largely on convenience (Field 1999).

\section{The Uni-link service}

Being the host to two large universities with a combined student population of 42190 (Higher Education Statistics Agency 2010), the City of Southampton is strongly influenced by its character as a university town. The Uni-link service, launched as a major campus-oriented bus service in 1998, is a major joint-venture transport initiative between the University of Southampton and a local bus operator, Bluestar. The objective of the venture is to provide convenient transportation between the five campuses, 20 halls of residence, sports centre and key locations within the City of Southampton for staff and students of the University whilst 
TABLE 2: Uni-link services.

\begin{tabular}{|c|c|c|c|}
\hline Route & Bus times & Start & $\begin{array}{l}\text { Final destination } \\
\text { (and vice versa) }\end{array}$ \\
\hline $\mathrm{U} 1$ & $\begin{array}{l}\text { Between every } 10 \\
\text { and } 20 \text { minutes }\end{array}$ & $\begin{array}{l}\text { Airport Parkway } \\
\text { Station }\end{array}$ & Dock Gate 4 \\
\hline U2 & $\begin{array}{l}\text { Every } 30 \text { minutes or } \\
\text { hourly }\end{array}$ & Civic Centre & $\begin{array}{l}\text { Bassett Green/ } \\
\text { Crematorium }\end{array}$ \\
\hline U6 & $\begin{array}{l}\text { Every } 30 \text { minutes or } \\
\text { hourly }\end{array}$ & Dock Gate 4 & General Hospital \\
\hline U9 & $\begin{array}{l}\text { Monday to Friday } \\
\text { three times a day }\end{array}$ & Townhill Park & Coxford Road \\
\hline
\end{tabular}

at the same time providing a bus service open to the general public. Since 2008, the Uni-link service has been operated by the bus operator Bluestar, a trading arm of the Go-Ahead Group, one of the leading bus and rail companies in the United Kingdom.

Uni-link covers four different campus bus routes (see Table 2). The 'U1' is Uni-link's most popular bus service with the company deploying only double-decker buses on this route.

Uni-link's competition comes from other bus operators that cover a total of 42 service routes within the city. Although Uni-link's routes and schedules are primarily tailored to meet the needs of University staff and students (timetabling, semester schedules and location of students' facilities), the service is also available for general public use, thus making its operations - particularly during student vacation periods - subject to indirect competition by other local bus operators.

It is perhaps important at this juncture to point out that whilst the 16 service attributes drawn from Eboli and Mazulla's (2007) study form the basis of assessment of the Uni-link service being examined in this study, subtle differences exist between their study and this one. The major difference is that whilst the bus service examined by Eboli and Mazulla focuses on a public transport service habitually used by students to reach campus, our focus is on examining levels of customer satisfaction with bus transportation services established primarily to serve students (and staff) of a university.

\section{Research methodology Questionnaire design}

To address the research questions, we employed a survey questionnaire. To take into account average bus journey times in the UK, which is estimated to be about 34 minutes (McLennan \& Bennetts 2003), we sought to streamline the questionnaire to a maximum of two pages (as a means of ensuring completion by respondents during a single bus journey). The questionnaire was also printed on both sides of one sheet of paper ${ }^{1}$.

We designed our questionnaire against three sections based on earlier studies conducted by Wall (Wall \& McDonald

1.We were conscious that some respondents may not notice the questionnaire continued on the flipside; for this reason, we distributed the questionnaire upside continued on the flipside; for this reason, we distributed the question
down, thus forcing the respondents to flip the questionnaire over.
2007; Wall et al. 2008), which identified the following key determinants of satisfaction with bus travel to include frequency, reliability, bus information, comfort of travel, friendliness of bus driver, driving of bus driver, appearance of bus shelters or stops, cleanliness, cost, route, time of travel, and socio-demographic variables. The first section of the questionnaire focused on socio-demographic questions, whilst the second section focused on factors such as journey purpose and frequency of use of service. In the last section of the questionnaire, we sought to gather information relating to service quality attributes based on bus service attributes earlier identified by Eboli and Mazzulla (2007). To achieve a higher completion rate, the responses were structured against a five-point Likert scale (Likert 1932).

\section{The fieldwork}

The fieldwork was undertaken over two consecutive weeks beginning on Sunday, 05 June 2011. To capture data from different respondents, data were recorded at random times between 08:00 hours and 23:00 hours. To achieve a good time efficacy, 20 clipboards and 20 ballpoint pens were distributed at any one point in time for the convenience of the respondent. In line with earlier works by Fernandez (2010) and Gu et al. (2011) that address how limitations with aligning and discharge flows degrade the overall service experience of bus passengers, in this particular study, we did not board any of the Uni-link buses at major bus stops. During the 2 weeks of data collection, a total of 847 respondents were sampled. In total, during the final count, 10 questionnaires were excluded either because of missing variables or because the respondent had only completed one side of the questionnaire. Data entry was conducted on SPSS Data Entry 4.0 primarily to mitigate against data entry mistakes. Additionally, unlike MS Excel, SPSS Data Entry 4.0 software reduces the time required to enter the data and also facilitated the initial definition of the variables. Structural equation modelling (SEM) was constructed on AMOS 19 (Shiftan, Outwater \& Zhou 2008).

\section{Analysis and results}

In summary, the majority of the respondents were male participants $(54.2 \%)$, whilst $45.8 \%$ of the respondents were female participants. The average age of the participants was 25.35 years, with a standard deviation of 7.977. This is not surprising as Uni-link customers are predominantly students. Of the student respondents, $97.9 \%$ stated their university as the University of Southampton whilst $0.4 \%$ indicated that they studied at Southampton Solent University (showing a strong association of the Uni-link brand with the University of Southampton). The purpose for service utilisation is shown in Table 3. The most common needs driving the utilisation of the service appeared to be 'shopping' (32.1\%) and 'social/leisure/visiting/recreation' $(30.3 \%)$. Our interpretation of the low responses in terms of 'Travel to/ from uni' may relate to the fact that data were gathered in June (near the end of term). 
TABLE 3: Purpose for service utilisation.

\begin{tabular}{|c|c|c|c|c|c|}
\hline Data & Most common needs driving the utilisation of the service & Frequency & $\%$ & Valid \% & Cumulative \% \\
\hline \multirow[t]{10}{*}{ Valid } & Travel to/from uni & 133 & 15.7 & 15.9 & 15.9 \\
\hline & Personal-medical & 22 & 2.6 & 2.6 & 18.5 \\
\hline & Talking/collecting someone & 11 & 1.3 & 1.3 & 19.8 \\
\hline & Travel during Uni & 15 & 1.8 & 1.8 & 21.6 \\
\hline & Travel to/from work & 102 & 12.0 & 12.2 & 33.8 \\
\hline & Taking/collecting children from school & 1 & 0.1 & 0.1 & 33.9 \\
\hline & Shopping & 269 & 31.8 & 32.1 & 66.1 \\
\hline & Social/leisure/visiting/recreation & 254 & 30.0 & 30.3 & 96.4 \\
\hline & Other & 30 & 3.5 & 3.6 & 100.0 \\
\hline & Total & 837 & 98.8 & 100.0 & - \\
\hline Missing & System & 10 & 1.2 & - & - \\
\hline Total & - & 847 & 100.0 & - & - \\
\hline
\end{tabular}

\section{Structural equation modelling} The structural equation model

All variables ascertained for the modelling are in ordinal measurement because of the labelling on a five-point Likert scale. More specifically, only those variables are taken into account which asked about the overall perceptions of Unilink's services in general, rather than about the bus service on the day of the bus journey. The model is calibrated with the specialist statistics software AMOS 19. The data violate normality, which might cause a poor fit but also support or identify expected directions of parameter estimates (Andreassen 1995). Still, normality and continuous-scale measurements are assumed for further analysis, as Pallant (2010) states that, in case of nonnormality, the results are only slightly affected when analysing a large data set. Maximum likelihood is used as the estimation method, which is the default procedure in AMOS and used by 'the majority of the marketing studies' (Andreassen et al. 1995:50). The aim is the construction of a hypothetical model that formulates the relationships between the aspects of the phenomenon of Uni-link's customer satisfaction. This abstract creation is supposed to reveal the theoretical phenomenon that cannot be observed directly.

\section{Initial structural equation model}

As our two research questions fundamentally involved the establishment of complex relationships, we employed SEM (Shah \& Goldstein 2006). The SEM we propose seeks to combine observed variables into related superior service quality areas. The initial SEM depicts four different service quality areas which summarise the assessed variables that are largely drawn from earlier work by Andreassen (1995) and Eboli and Mazzulla (2007). Figure 1 shows the relationships between the four different service quality areas and overall customer satisfaction that are articulated in the SEM whilst Table 4 shows the constructs (service quality areas) and the variables (items) of the four different service quality areas.

The rectangles on the left of Figure 1 are the 16 variables that were assessed in section $C$ of the questionnaire. They are observed variables (as they are directly measured on a five-point Likert scale) and determine the ellipses connected to them. Accordingly, the ellipses represent the four different service quality areas, which are unobserved variables in the model. In the figure, the path coefficient estimates are indicated as standardised values. The standardised values are chosen in this case to simplify the comparisons amongst themselves (Anderson et al. 2010). In the structural equation model, the construct Planning and Reliability shows the strongest effect on O_satisfaction. This is indicated by the value in the middle of the arrow, which is 0.66 . According to the model, the second strongest effect comes from the construct Driver, that is 0.41 . The construct Routes has a weaker effect on $O \_s a t i s f a c t i o n$ with 0.14 . All those values are positive; thus, higher satisfaction levels in the service quality areas would lead to a higher overall satisfaction. The difference of the values indicates the strength of the effects of the different service quality areas on O_satisfaction.

The constructs were tested for their internal reliabilities to examine whether the included items, combined, represent a consistent measure. In this respect, the values of Cronbach's coefficient alpha (Cronbach 1951) are shown in Table 5.

The Cronbach's alpha $(\alpha)$ values range between 0.618 (construct Service) and 0.824 (construct Driver). For basic research, Nunnally (1967) suggests Cronbach's alpha values of above 0.5 (this is later raised to 0.7; see Nunnally 1978). In terms of Goodness of fit, which measures how well the hypothesised model fits the sample data, possible indices range from zero (0) to 1.0 , whereby values close to 1.0 imply a good fit of the model (Joreskog \& Sorbom 1993). The values of the Goodness of fit indices of the initial model are stated in Table 6. For the comparative fit index, Hu and Bentler (1999) considered a value $>0.95$ as representative of a model with a good fit.

Based on the Goodness-of-fit index (GFI) and Adjustedgoodness-of-fit index (AGFI) values of 0.913 and 0.879 , respectively, it can be concluded that the hypothesised model fits the sample data well. Also the comparative fit index value suggests that the model fit is adequate. In terms of the Path coefficients of this initial model, the standardised path coefficients of the initial model were chosen to simplify the comparisons amongst themselves (see Anderson et al. 2010). In the initial structural equation model (with standardised estimates), the construct Planning_Reliability 


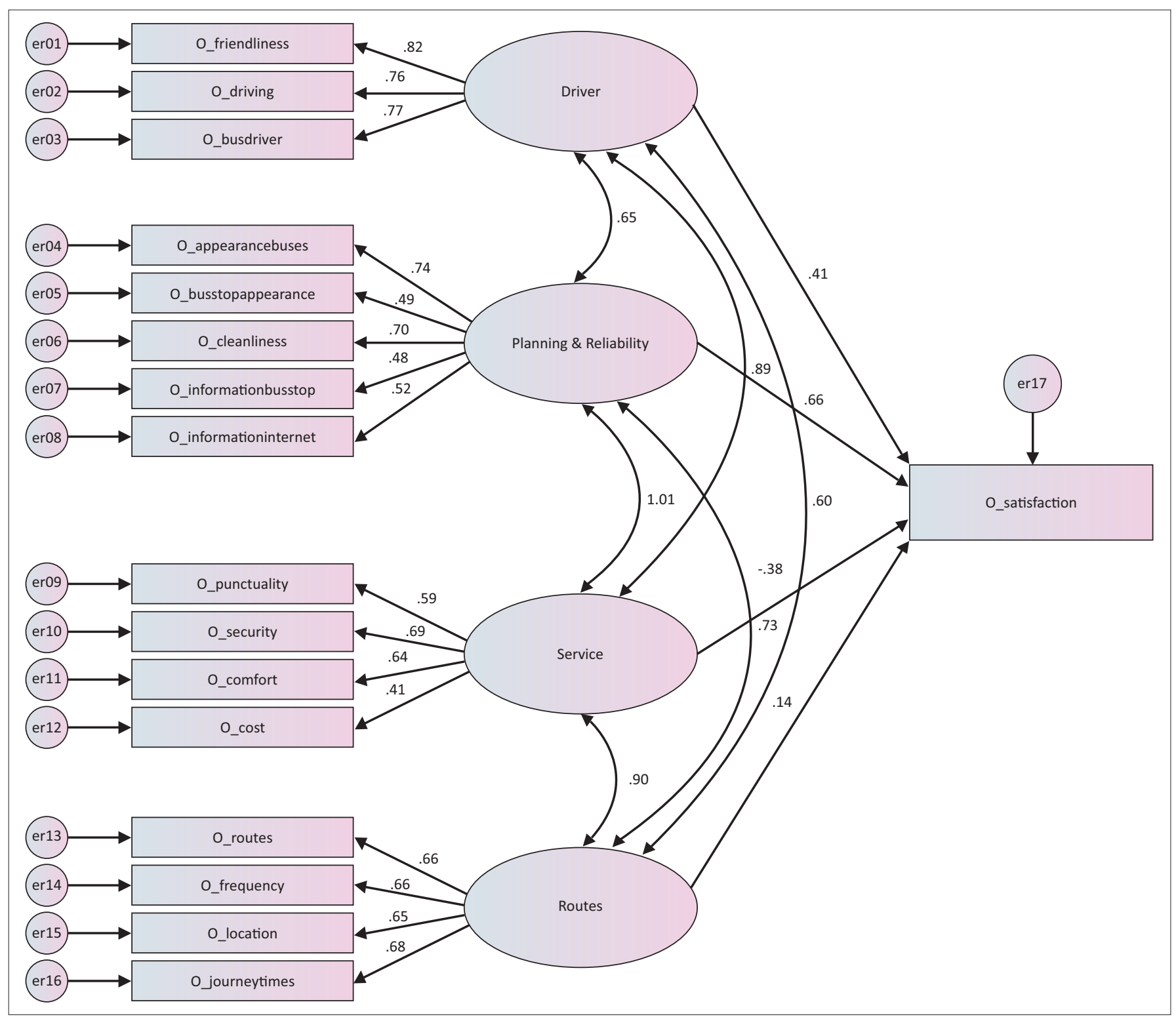

Source: Authors' own creation; IBM SPSS Amos

FIGURE 1: Initial structural equation model (with standardised estimates).

TABLE 4: Variable 'purpose'.

\begin{tabular}{lll}
\hline $\begin{array}{l}\text { Service quality } \\
\text { area or construct }\end{array}$ & Underlying variables & Definitions \\
\hline Driver & O_friendliness & Friendliness of bus driver \\
& O_driving & Driving of bus driver \\
& O_busdriver & Overall satisfaction with bus driver \\
Planning and & O_appearancebus & Appearance of buses \\
Reliability & O_busstopappearance & Appearance of bus stops \\
& O_cleanliness & Cleanliness of buses \\
& O_informationbusstop & Information at bus stops \\
& O_informationinternet & Information on the Internet \\
Service & O_punctuality & Punctuality \\
& O_security & Feeling of security \\
& O_comfort & Comfort \\
& O_cost & Cost \\
Routes & O_routes & Routes \\
& O_frequency & Frequency \\
& O_location & Location \\
& O_journeytimes & Journey times \\
\hline
\end{tabular}

has shown the strongest effect on O_satisfaction (0.66). The construct Routes has a weaker effect on O_satisfaction (0.14), implying that higher satisfaction levels in the service quality areas would lead to a higher overall satisfaction. The difference of the values indicates the strength of the effects of the different service quality areas on O_satisfaction. On the account that the negative effect of the construct Service on overall satisfaction is doubtful, the construct Service would imply that a high satisfaction level of the service quality could lead to a lower level of overall satisfaction with Uni-link's bus service. This explanation may, however, need further investigation as there is very limited work describing how a negative direction in a service quality area may increase the overall customer satisfaction. Furthermore, the significance levels are low for the effects of the constructs Service and Routes on $O \_$satisfaction at a $p$-value $<0.05$. 
TABLE 5: Internal reliability (initial model).

\begin{tabular}{lcc}
\hline Construct & Number of items included & Cronbach's alpha $(\boldsymbol{\alpha})$ \\
\hline Driver & 3 & 0.824 \\
Planning and Reliability & 5 & 0.729 \\
Service & 4 & 0.618 \\
Routes & 4 & 0.759 \\
\hline
\end{tabular}

TABLE 6: Goodness of fit indices initial model.

\begin{tabular}{ll}
\hline Index & Value \\
\hline Goodness of fit index & 0.913 \\
Adjusted goodness of fit index & 0.879 \\
Comparative fit index & 0.902 \\
\hline
\end{tabular}

The analysis of the initial model (Table 7) shows that there is room for improvement and modifications, even though we found compelling values in terms of the Goodness of fit indices. However, the initial model does not seem to replicate customer satisfaction correctly; therefore, it is modified and an improved final model is analysed in the next subsection.

\section{Final structural equation model}

In the initial model, the variable Cost $\left(O_{-} \cos t\right)$ was included as one of the four underlying variables of the 'service' construct. In the final model, which is shown as Figure 2, O_cost is not included in any construct but has the function of a moderating variable as it influences the other constructs. The assumption of the moderating impact of cost on service quality is made based on earlier studies. For example, Sharma (2003) explicitly identifies cost as an independent moderator in customer-service-provider relationships. The model was amended because the construct 'service' was deleted as a result of the negative effect it had on the model because of generally lower model parameter estimation and significance levels (see Table 7). However, we made a decision not to drop the higher ranking individual attributes, of O_security, O_comfort and O_punctuality, instead choosing to move O_security and O_comfort to another closely aligned service quality area, Planning Reliability. The modification of the initial model led to the final model described above and is shown in Figure 2, with improved values.

As the attribute O_punctuality appeared by definition more aligned to 'Routes', this was removed as well. The remaining three constructs and the variables are shown in Table 8.

In our Internal test of reliability of the final model, Cronbach's coefficient alpha $(\alpha)$ values were calculated to measure the level of agreement between the variables (Table 9).

This time, all Cronbach's coefficients have values $\geq 0.7$, which are scattered around 0.8 . This is indicative of good internal consistence and reliability (see Nunnally 1978). Analysis of the Goodness of fit indices (Table 10) shows that the indices of the final model slightly improved over those of the initial model (as shown in Table 6). The values are spread around 0.9 , which represents a good model fit of the sample data (see Joreskog \& Sorbom 1993).

When we examined the path coefficients of the final model, we observed that all three constructs - Driver, Planning Reliability and Routes_Service - now indicate a positive relationship with O_satisfaction. The construct Planning Reliability has the strongest effect on O_satisfaction, with a standardised value of 0.49 . However, Routes_Service shows a weak impact on O_satisfaction with a value of 0.06 . Routes Service on the other hand has a latent variable with 0.47 , whilst Planning_Reliability and Driver show 0.34 and

TABLE 7: Initial model attribute estimation and significance levels.

\begin{tabular}{|c|c|c|c|c|c|c|}
\hline Underlying variables & Service quality area & Estimate & Standardised estimate & S.E. & C.R. & $P$ \\
\hline O_busdriver & $\leftarrow$ Driver & 1.000 & 0.77 & - & - & - \\
\hline O_driving & $\leftarrow$ Driver & 1.040 & 0.76 & 0.051 & 20.533 & $* * *$ \\
\hline O_friendliness & $\leftarrow$ Driver & 1.037 & 0.82 & 0.048 & 21.838 & $* * *$ \\
\hline O_cleanliness & $\leftarrow$ Planning_Reliability & 1.000 & 0.70 & - & - & - \\
\hline O_busstopappearance & $\leftarrow$ Planning_Reliability & 0.728 & 0.49 & 0.059 & 12.233 & $* * *$ \\
\hline O_appearancebuses & $\leftarrow$ Planning_Reliability & 0.977 & 0.74 & 0.055 & 17.778 & $* * *$ \\
\hline O_informationbusstop & $\leftarrow$ Planning_Reliability & 0.763 & 0.48 & 0.064 & 11.939 & $* * *$ \\
\hline O_informationinternet & $\leftarrow$ Planning_Reliability & 0.805 & 0.52 & 0.062 & 12.899 & $* * *$ \\
\hline O_comfort & $\leftarrow$ Service & 1.000 & 0.64 & - & - & - \\
\hline O_security & $\leftarrow$ Service & 0.990 & 0.63 & 0.061 & 16.251 & $* * *$ \\
\hline O_punctuality & $\leftarrow$ Service & 1.083 & 0.59 & 0.070 & 15.399 & $* * *$ \\
\hline O_cost & $\leftarrow$ Service & 0.935 & 0.41 & 0.085 & 11.038 & $* * *$ \\
\hline$O_{-}$frequency & $\leftarrow$ Routes & 1.000 & 0.66 & - & - & - \\
\hline O_routes & $\leftarrow$ Routes & 0.938 & 0.66 & 0.063 & 14.912 & $* * *$ \\
\hline O_journeytimes & $\leftarrow$ Routes & 1.020 & 0.68 & 0.066 & 15.347 & $* * *$ \\
\hline O_satisfaction & $\leftarrow$ Service & -0.557 & -0.38 & 0.297 & -1.877 & .061 \\
\hline O_satisfaction & $\leftarrow$ Planning_Reliability & 0.854 & 0.66 & 0.162 & 5.269 & $* * *$ \\
\hline O_satisfaction & $\leftarrow$ Routes & 0.167 & 0.14 & 0.110 & 1.512 & .131 \\
\hline O_satisfaction & $\leftarrow$ Driver & 0.447 & 0.41 & 0.101 & 4.444 & $* * *$ \\
\hline
\end{tabular}

S.E., standard error; C.R., critical ratio; $P, p$-value.

***, $p$-value is less than 0.001 


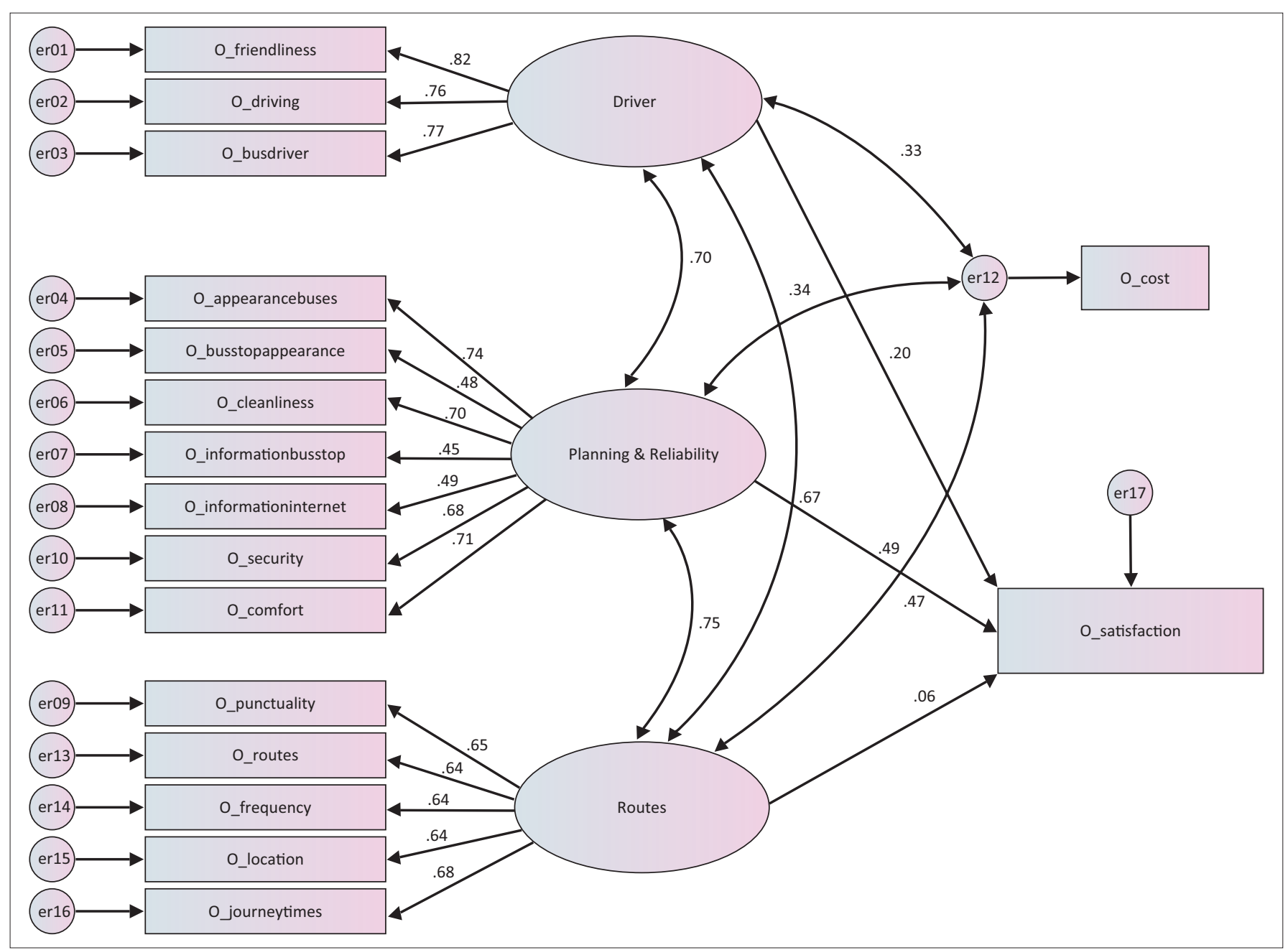

Source: Authors' own creation; IBM SPSS Amos

FIGURE 2: Final structural equation model (with standardised estimates).

TABLE 8: Service quality areas of the final model.

\begin{tabular}{ll}
\hline Service quality area & Underlying variables \\
\hline Driver & Friendliness of bus driver (O_friendliness) \\
& Driving of bus driver (O_driving) \\
& Overall satisfaction with bus driver (O_busdriver) \\
Planning_Reliability & Appearance of buses (O_appearancebus) \\
& Appearance of bus stops (O_busstopappearance) \\
& Cleanliness of buses (O_cleanliness) \\
& Information at bus stops (O_informationbusstop) \\
& Information on the Internet (O_informationinternet) \\
& Security feeling (O_security) \\
& Comfort (O_comfort) \\
& Punctuality (O_punctuality) \\
Routes_Service & Routes (O_routes) \\
& Frequency (O_frequency) \\
& Location (O_location) \\
& Journey times (O_journeytimes) \\
& Cost (O_cost)
\end{tabular}

0.33 , respectively. The significance levels and unstandardised estimates of the final model are shown in Table 11.

In Table 10, we observe that all path coefficients are significant at a $p$-value $<0.05$, except the impact of Routes_ Service on O_satisfaction. The overall measure for the construct Planning_Reliability (A_Planning_Reliability) in Table 11 shows
TABLE 9: Internal reliability (final model)

\begin{tabular}{lcc}
\hline Construct & Number of items included & Cronbach's alpha \\
\hline Driver & 3 & 0.824 \\
Planning_Reliability & 7 & 0.802 \\
Routes_Service & 5 & 0.787 \\
\hline
\end{tabular}

TABLE 10: Goodness of fit indices final model.

\begin{tabular}{ll}
\hline Index & Value \\
\hline Goodness of fit index & 0.915 \\
Adjusted goodness of fit index & 0.884 \\
Comparative fit index & 0.902 \\
\hline
\end{tabular}

a mean value of 1.9288 , followed by $A \_$Routes_Service (2.0091) and $A \_$Driver (2.0156). Analysis of variance is now used to test if the level of crowdedness on the bus routes shows significant differences in the means of the overall measures A_Driver, A_Planning_Reliability and A_Routes_Service. Summations of the underlying variables are shown in Table 12.

The calculated means follow in Table 13.

Crowdedness and service quality areas: The level of crowdedness on the bus (from $5=$ 'very crowded' to $1=$ 'very uncrowded') was used to obtain an estimate of the 
TABLE 11: Final model attribute estimation and significance levels.

\begin{tabular}{|c|c|c|c|c|c|c|}
\hline Underlying variables & Service quality area & Estimate & Standardised estimate & SE & C.R. & $p$ \\
\hline O_busdriver & $\leftarrow$ Driver & 1.000 & 0.77 & - & - & - \\
\hline O_driving & $\leftarrow$ Driver & 1.026 & 0.76 & 0.051 & 20.315 & $* * *$ \\
\hline O_friendliness & $\leftarrow$ Driver & 1.036 & 0.82 & 0.048 & 21.767 & $* * *$ \\
\hline O_cleanliness & $\leftarrow$ Planning_Reliability & 1.000 & 0.70 & - & - & - \\
\hline O_busstopappearance & $\leftarrow$ Planning_Reliability & 0.708 & 0.48 & 0.058 & 12.141 & $* * *$ \\
\hline O_appearancebuses & $\leftarrow$ Planning_Reliability & 0.984 & 0.74 & 0.053 & 18.412 & $* * *$ \\
\hline O_informationbusstop & $\leftarrow$ Planning_Reliability & 0.714 & 0.45 & 0.063 & 11.404 & $* * *$ \\
\hline O_informationinternet & $\leftarrow$ Planning_Reliability & 0.764 & 0.49 & 0.061 & 12.513 & $* * *$ \\
\hline O_security & $\leftarrow$ Planning_Reliability & 0.943 & 0.68 & 0.055 & 17.046 & $* * *$ \\
\hline O_comfort & $\leftarrow$ Planning_Reliability & 0.980 & 0.71 & 0.055 & 17.756 & $* * *$ \\
\hline O_frequency & $\leftarrow$ Routes_Service & 1.000 & 0.64 & - & - & - \\
\hline O_routes & $\leftarrow$ Routes_Service & 0.940 & 0.64 & 0.064 & 14.693 & $* * *$ \\
\hline O_location & $\leftarrow$ Routes_Service & 0.916 & 0.64 & 0.063 & 14.644 & $* * *$ \\
\hline O_journeytimes & $\leftarrow$ Routes_Service & 1.040 & 0.68 & 0.068 & 15.339 & $* * *$ \\
\hline O_satisfaction & $\leftarrow$ Routes_Service & 0.073 & 0.06 & 0.072 & 1.016 & 0.310 \\
\hline O_satisfaction & $\leftarrow$ Planning_Reliability & 0.639 & 0.49 & 0.083 & 7.695 & $* * *$ \\
\hline O_satisfaction & $\leftarrow$ Driver & 0.221 & 0.20 & 0.055 & 4.010 & $* * *$ \\
\hline
\end{tabular}

S.E., standard error; C.R., critical ratio; $p, p$-value.

$* * *, p$-value is less than 0.001

TABLE 12: New overall measures.

\begin{tabular}{|c|c|c|}
\hline Service quality area & Underlying variables & New overall measure \\
\hline \multirow[t]{3}{*}{ Driver } & $\begin{array}{l}\text { Friendliness of bus driver } \\
\text { (O_friendliness) }\end{array}$ & A_Driver \\
\hline & Driving of bus driver ( $O_{-}$driving) & \\
\hline & $\begin{array}{l}\text { Overall satisfaction with bus driver } \\
\text { (O_busdriver) }\end{array}$ & \\
\hline \multirow[t]{7}{*}{ Planning_Reliability } & $\begin{array}{l}\text { Appearance of buses } \\
\text { (O_appearancebus) }\end{array}$ & A_Planning_Reliability \\
\hline & $\begin{array}{l}\text { Appearance of bus stops } \\
\text { (O_busstopappearance) }\end{array}$ & \\
\hline & Cleanliness of buses ( $O \_$cleanliness) & \\
\hline & $\begin{array}{l}\text { Information at bus stops } \\
\text { (O_informationbusstop) }\end{array}$ & \\
\hline & $\begin{array}{l}\text { Information on the Internet } \\
\text { (O_informationinternet) }\end{array}$ & \\
\hline & Security feeling ( $O \_$security) & \\
\hline & Comfort (O_comfort) & \\
\hline \multirow[t]{5}{*}{ Routes_Service } & Punctuality (O_punctuality) & A_Routes_Service \\
\hline & Routes (O_routes) & \\
\hline & Frequency ( $O_{-}$frequency) & \\
\hline & Location (O_location) & \\
\hline & Journey times (O_journeytimes) & \\
\hline
\end{tabular}

TABLE 13: Means of overall measures.

\begin{tabular}{ll}
\hline Overall measure & Mean \\
\hline A_Driver & 2.0156 \\
A_Planning_Reliability & 1.9288 \\
A_Routes_Service & 2.0091 \\
\hline
\end{tabular}

space available to passengers (a more meaningful means of comparison of crowdedness on double-decker and single-decker buses). The means of the service quality areas and the different levels of crowdedness are shown in Table 14.

For the service quality areas grouped by crowdedness, the analysis of variance (ANOVA) shows a statistically significant difference at $p$-value $<0.05$. The statistically significant differences exist in the service quality area A_Planning_Reliability and between the crowdedness levels 4 and 1, as well as 4 and 2 (Eta squared $=0.022$ ). Further, a statistically significant difference can be found in the service quality area A_Routes_Service between the crowdedness levels 3 and 1 as well as 3 and 2 (Eta squared $=0.017$ ).

Routes/frequency and service quality areas: The ANOVA (Table 15) found a statistically significant difference at the $p$-level $<0.05$ for A_Driver for the different routes as well as A_Planning_Reliability for the different routes with Eta squared effect sizes of 0.016 and 0.014 , respectively.

\section{Discussion}

The outcome of the SEM analysis is that three different service attributes - Driver, Planning_Reliability and Routes_ Service - are seen to significantly impact customer service satisfaction, thus addressing the first research question (What service attributes significantly influence the satisfaction of customers using bus services?). Our findings are in line with extant literature not only on the moderating role of cost on services (see Sharma 2003), but also on the role that frontline employees in campus bus transportation service providers play in the customer's service satisfaction (Ellinger, Keller \& Baş 2010). In addition, also in line with existing literature (Diana 2012; Hensher et al. 2003; Salicru, Fleurent \& Armengol 2011), it was expected that variables such as frequency, punctuality and journey times, all of which measure the construct Routes_Service, would have a high impact on customer satisfaction; however, this construct, that is Routes_Service, had a low standardised path coefficient of 0.06. On the other hand, in line with earlier studies (Eboli \& Mazzulla 2011; Politis et al. 2010; Wall \& McDonald 2007), Planning_Reliability has a high impact on customer satisfaction. In the case of our model, this construct had a path coefficient of 0.49 .

It might be the case that the variables that measure Routes Service, that is punctuality, routes, frequency, location of bus stops and journey times, are hygiene factors, which do not 
TABLE 14: Means of crowdedness and service quality areas.

\begin{tabular}{|c|c|c|c|c|c|}
\hline Service quality area & Area & $N$ & Mean & SD & SE \\
\hline \multirow[t]{6}{*}{ A_Driver } & 1 & 131 & 2.1069 & 0.65276 & 0.05703 \\
\hline & 2 & 221 & 2.0920 & 0.69564 & 0.04679 \\
\hline & 3 & 189 & 1.9330 & 0.71059 & 0.05169 \\
\hline & 4 & 137 & 1.9270 & 0.64133 & 0.05479 \\
\hline & 5 & 93 & 2.0036 & 0.67297 & 0.06978 \\
\hline & Total & 771 & 2.0156 & 0.68295 & 0.02460 \\
\hline & 2 & 221 & 1.9942 & 0.45935 & 0.03090 \\
\hline & 3 & 189 & 1.8874 & 0.57005 & 0.04147 \\
\hline & 4 & 137 & 1.8363 & 0.53831 & 0.04599 \\
\hline & 5 & 93 & 1.8510 & 0.48533 & 0.05033 \\
\hline & Total & 771 & 1.9288 & 0.50328 & 0.01813 \\
\hline \multirow[t]{5}{*}{ A_Routes_Service } & 1 & 131 & 2.1115 & 0.50056 & 0.04373 \\
\hline & 2 & 221 & 2.0796 & 0.53952 & 0.03629 \\
\hline & 4 & 137 & 1.9679 & 0.65135 & 0.05565 \\
\hline & 5 & 93 & 1.9527 & 0.65832 & 0.06826 \\
\hline & Total & 771 & 2.0091 & 0.59876 & 0.02156 \\
\hline
\end{tabular}

TABLE 15: Routes and service quality areas.

\begin{tabular}{|c|c|c|c|c|c|}
\hline Service quality area & Route & $N$ & Mean & SD & SE \\
\hline \multirow[t]{4}{*}{ A_Driver } & U1 & 529 & 2.0668 & 0.69036 & 0.03002 \\
\hline & U2 & 129 & 1.8320 & 0.61678 & 0.05430 \\
\hline & U6 & 113 & 1.9853 & 0.68775 & 0.06470 \\
\hline & Total & 771 & 2.0156 & 0.68295 & 0.02460 \\
\hline \multirow[t]{4}{*}{ A_Planning_Reliability } & U1 & 529 & 1.9533 & 0.51269 & 0.02229 \\
\hline & U2 & 129 & 1.7951 & 0.43735 & 0.03851 \\
\hline & U6 & 113 & 1.9671 & 0.50867 & 0.04785 \\
\hline & Total & 771 & 1.9288 & 0.50328 & 0.01813 \\
\hline \multirow[t]{4}{*}{ A_Routes_Service } & U1 & 529 & 2.0265 & 0.61550 & 0.02676 \\
\hline & U2 & 129 & 1.9442 & 0.56788 & 0.05000 \\
\hline & U6 & 113 & 2.0018 & 0.55129 & 0.05186 \\
\hline & Total & 771 & 2.0091 & 0.59876 & 0.02156 \\
\hline
\end{tabular}

necessarily lead to customer satisfaction. Regarding the underlying case of customer satisfaction, it might be that those variables are important, even though this is not directly implied by our results. The service quality area, Planning Reliability showed the greatest impact on customer satisfaction (0.49) amongst the three constructs. This emphasises the importance of the underlying variables that contribute most to the construct; namely, appearance of the bus (0.74), cleanliness (0.7), security feeling (0.68) and comfort (0.71). Those variables all aim to ascertain customers' perceptions on the buses, that is how passengers perceive the overall experience of their bus journey.

In terms of the second research question (Does customer satisfaction vary depending on bus transport route and frequency?), the ANOVA showed that there were statistically significant differences between the service quality areas and bus routes and frequency. Nevertheless, the effect size measured by the Eta squared indicated small effects on the difference in means. Pallant (2010) argues that even though some results of the ANOVA might indicate statistical significance, the interpretation can be impractical when mean scores only differ slightly. With a large sample, small differences in mean scores might become statistically significant, although the difference between the groups has only limited practical meaning (Pallant 2010).

\section{Conclusion}

The study examined the determinants of satisfaction with campus bus transportation. The research reflected scholarly interest on the selection of modes of transport service, but specifically that related to buses - a mode of transport characterised by its popularity. Within this context, the study also explored possible implications of satisfaction with such campus bus transportation for service quality. The study is of particular relevance to logistics research for a number of reasons including the fact that universities and other institutions of higher education are increasingly embracing the concept of campus shuttle services in order to reduce costs - for example, those relating to parking operations. More specifically, Farzaneh et al. (2009:vi) suggest that such strategies 'have positive impact on the liveability of the campus and surrounding neighbourhoods and can provide substantial fiscal benefits for the university...'. Traditionally, worldwide, the transportation systems of most universities had been predominantly car-dependent. However, in light of emerging concerns relating to safety, noise and pollution, and the demand for land required to build and operate parking facilities, mainly for single-occupancy vehicles, the operation of 'dedicated' campus bus transportation (shuttles) has become increasingly popular. Taking this into consideration, this study presented two research questions: (1) What service 
attributes significantly influence the satisfaction of students using campus bus services? and (2) Does customer satisfaction vary depending on bus transport route and frequency?

In terms of the first research question (What service attributes significantly influence the satisfaction of students using campus bus services?), based on the outcome of the SEM analysis, we found that three different service attributes-Driver,Planning_Reliability and Routes_Servicesignificantly impacted upon customer service satisfaction with campus bus transportation. In terms of the second research question (Does customer satisfaction vary depending on bus transport route and frequency?), overall, results from our study suggested that customer satisfaction varied depending on bus transport route and frequency.

The study also has considerable implications - in particular, noting that a fundamental objective of services theory focuses on developing an appreciation of not only the service experience of customers but also the way that those experiences are evaluated (Buffa \& Ross 2011).

As earlier highlighted, scholarship emphasises that positively evaluated service experiences are primary drivers of customer loyalty and trust in high-contact service scenarios, such as bus transportation. But for what purposes can customer service experience data be used? Consider that, because of contractual guarantees, as a service established to predominantly cater for university students (and staff), arguably, the Uni-link service may be perceived to operate a near monopoly over campus bus services in Southampton. The key implication for managers is that the operators of the Uni-link service in this case lack obvious competitive pressures to improve service satisfaction and performance. The danger here is that one of the managers (or more than one) may succumb to complacency with respect to service quality, which may damage trade-off decisions where cost reduction takes priority over maintaining and improving the quality of service provided to its customers. Hence, the firm might usefully manufacture their own clear incentives. A first step is to conceive of service improvement as something more than reactive fire-fighting in response to dips in performance on explicitly stated and identified customer experience attributes. One way forward for the operators of the Uni-link service is to focus more on one, one additional very specific measure of service satisfaction, 'customer accountability'. Through the provision of transparent customer service indicators, derived from and improved through consultation with customers themselves, the service operator might use customer discipline as a substitute to clearly manifest market discipline in driving forward enhanced service quality improvements. This, though, would hinge upon the determination of Uni-link management to report to its newly constituted 'passenger panels' with a clear mandate to demonstrate quality improvement to them (dependent on how the panels interpret 'quality') instead of simply using the panels to determine isolated 'local' incidents and issues requiring isolated managerial responses. It thus appears that an opportunity for further study may involve examining bus services under different market conditions. One such condition may involve full competition along Unilink's preferred routes. Such studies will also be beneficial to scholars interested in understanding which service attributes play critical roles under different service conditions.

Whilst transport services operating in a fully competitive environment may seek to utilise service evaluation data to attract and retain customers by improving the efficiency of internal processes and operation, one could argue that, for firms offering dedicated services such as the operators of Uni-link, the main focus on service provision may need to switch from service evaluation to customer evaluation under conditions of improved transparency and accountability to customers. However, crucially, service evaluation data and processes are only useful to the extent that they provide an evidence base for managerial action to enhance or at least meet customer satisfaction expectations. Fundamentally, this entails focusing on weaknesses rather than the strengths that managers may prefer to focus on for purposes of performance evaluation. Of course, in a service environment established to predominantly service university students (and staff), such as the Uni-link services, the reality is that it may prove challenging to measure the hotspots of negative affect that influence customer satisfaction for a number of reasons including, for example problems where highly vocal individuals influence group discussions on customer panels. Another issue is that managers may come under pressure to also accede to different expectations of wider stakeholder groups (which in this case comprises students, the University and the Local Council). Conceivably, a range of stakeholder opinions might vary by individual bus route, which makes it important to privilege customer data based on direct service experiences rather than on general impressions of overall service levels.

Our research does show some general trends; yet the insight these trends yield of services at the individual route level ought to be demonstrated rather than assumed. Earlier studies that focused on service delivery challenges in the public sector (see Kelly 2005) suggest that, instead of engaging with these issues, service delivery managers are likely to 'focus their attention on internal measures of service delivery and not on external measures of value creation from consumers' (Kelly 2005:77). However, Kelly (2005) further suggests that service delivery decisions are best made where managers are able to harness inputs from customers who have been reasonably acquainted with information, which then enables them to conduct their own service quality assessments. Taking stock of Kelly's observations, we suggest that, if they are to rise to their service delivery challenges and so maintain or improve their market positions, bus transportation service providers that predominantly service university students (and staff) such as Uni-link need to (re) consider the interrelationship between risk of financial loss and service quality. Clearly, competitiveness is a function of service quality, and so the mitigation of risk of financial loss (particularly in near-service environments where specific 
competitive threats are not readily manifest and therefore not readily amenable to individually tailored risk-control activities) entails the general pursuit of quality improvement. Quality improvement, of course, entails exploiting opportunities for service innovation. However, as with all innovations the effect of quality improvement in this case is not automatically to reduce risk, but rather to modify the campus bus transportation service provider's exposure to risk. After all, innovations can be unsuccessful - they can be cost-ineffective and may carry reputational penalties that are difficult to quantify in financial terms. Amongst innovating dedicated campus bus transportation service providers, innovations often have both their promoters (who emphasise risks associated with failing to innovate) and their detractors (who emphasise risks brought by innovation) (see Marshall \& Ojiako 2010). Given the uncertain and trial-and-error nature of service innovation, then, it makes sense to widen the service providers' 'innovation debate' by maybe having customer panels 'plugged in' as consultees to service innovation processes. This could be undertaken on both an $e x$ ante basis and an ex post basis to service innovations, which may include actually changing the entire competitive landscape that presents students with alternative options when they need to shuttle on and off campus. One such approach may include service providers such as Uni-link collaborating with the University to invest more heavily in embracing blended learning. For example, increased use of Virtual Learning Environments may reduce the need for students to have to be physically present on campus at specific times. Its effect would be to attune the service provider on an ongoing basis to the effects of service innovations upon customer experiences of service quality, in whatever terms customers choose to frame their experiences. In effect, customer-dominant logic can then exert a positive influence on business logic.

In conclusion, the paper provides useful insight into the range of customer experience factors that may be relevant with respect to any given service innovation, but we stress that a viable understanding of customer experience, useful for a healthy customer-manager debate that can help steer service innovation over time, can only emerge where there is effective and ongoing communicativity and dialogue between customers and managers at the interface between customer logic and business logic. In sum, the contributions of the paper not only lie in undertaking the examination of service attributes and their influences on customer satisfaction in campus bus transportation but also in emphasising that managerial attention to service user experiences in predominantly dedicated transportation services alone will fail to deliver competitive success. Instead, management should invest additional effort to significantly enrich service by paying greater attention to the interface between risk of financial loss and service quality. We posit that our findings are valuable as promptuaries or 'touchstones' which can be used to encourage customers, for example on the Bluestar (another bus company) customer panels, to offer better informed and more nuanced views of their customer experiences. For example, if presented with our findings, customers would be able to comment on whether existing metrics seem adequate, and they may simultaneously be disciplined by findings based on these metrics, thus being more cautious and realistic when purporting to represent the general views of customers. The effect of this is likely to be benign, because it will help localise discussions at the level of actual customer experiences and the (customer) emotions they evoke.

As expected, this study was not without limitations. Four main limitations are identified. Firstly, examining the data shows that the actual number of bus passengers going to the university was 133 out of 847 , representing approximately $15 \%$ of the Unilink service. A possible reason for this lower-than-desired sample could be related to the fact that the data were gathered towards the end of term (which ended on 18 June), at a time when the majority of students were taking their examinations. Another possible reason could be that a lower-than-anticipated number of students utilise the service. Thus, to improve both response rates, future studies could focus on not only undertaking the collection of data perhaps in mid-term (when most students are likely to be on campus) but by conceptualising the study in a much broader way - for example not limiting interest to students. For example, it will be of interest to gain an understanding of why members of the wider public will choose to utilise such services (in the absence of routing considerations). Secondly, by assuming homogeneity in service provision of bus services, although taking specific determinants of satisfaction such as routing into consideration (in the design of the questionnaire), the future possible impact of future direct competition from other bus operators was not taken into consideration in the current study. Such consideration will be imperative in future studies. The third limitation relates to the grouping of the variables (particularly in the service quality areas of the final SEM model). The attribute categorisation was driven by shared interpretation of meaning or definition by the authors. For future studies, a more 'scientific' approach to grouping is recommended to ensure greater model robustness. The final limitation relates to an acknowledgement that the study did not undertake any assessment of the respondents' cognitive mode (process of thought), although the literature (see Amit \& Sagiv 2013; Church 1997) does infer that perceptions are influenced by such mental modes. Thus, in reality, the study only captured the views of respondents that were explicitly expressed. Fisk and Haase (2011) highlight the importance of implicitly held perceptions in decision making. Again, this limitation presents considerable opportunities for future research directions.

\section{Acknowledgements Competing interests}

The authors declare that they have no financial or personal relationships which may have inappropriately influenced them in writing this article.

\section{Authors' contributions}

F.C., U.O., M.C. A.M. all made equal conceptual contributions that led to the development of this article. 


\section{References}

Ahn, K., 2009, 'Road pricing and bus service policies', Journal of Transport Economics and Policy 43(1), 25-53.

Amit, A. \& Sagiv, L., 2013, 'The role of epistemic motivation in individuals' response to decision complexity', Organizational Behaviour and Human Decision Processes 121(1), 104-117.

Andaleeb, S., Haq, M. \& Ahmaed, R., 2007, 'Reforming innercity bus transportation in developing country', Journal of Public Transportation 10(1), 1-25.

Anderson, D., Sweeney, D., Williams, T., Freeman, J. \& Shoesmith, E., 2010, Statistic for business and economics, 2nd edn., Cengage Learning EMEA, Andover, MA.

Andreassen, T., 1995, '(Dis) satisfaction with public services: The case of public transportation', Journal of Services Marketing 9(5), 30-41.

Aurier, P. \& Guintcheva, G., 2014, 'Using affect-expectations theory to explain the direction of the impacts of experiential emotions on satisfaction', Psychology \& Marketing 31(10), 900-913.

Balsas, C., 2006, 'Transportation and sustainable campus communities: Issues, examples, and solutions review', Journal of American Planning Association 72(3), 369-470.

Bamberg, S. \& Schmidt, P., 2003, 'Incentive, morality or habit? Predicting students' car use for university routes with the models of Ajzen, Schwartz, and Triandis', Environment \& Behaviour 35, 1-22.

Bhattacharya, A., Kumar, S.A., Tiwari, M.K. \& Talluri, S., 2014, 'An intermodal freigh transport system for optimal supply chain logistics', Transportation Research Part C: Emerging Technologies 38, 73-84.

Bond, A. \& Steiner, R., 2006, 'Sustainable campus transportation through transit partnership and transportation demand management: A case study from the University of Florida', Berkley Planning Journal 19, 125-142.

Bonney, M. \& Jaber, M., 2014, 'Deriving research agendas for manufacturing and logistics systems: A methodology', International Journal of Production Economics $157,49-61$

Broome, K., Worrall, L., Fleming, J. \& Boldy, D., 2012, 'Evaluation of flexible route bus transport for older people', Transport Policy 21, 85-91.

Buffa, F. \& Ross, A., 2011, 'Measuring the consequences of using diverse supplier evaluation teams: A performance frontier perspective', Journal of Business Logistics 32(1), 55-68.

Burton, S., Sheather, S. \& Roberts, J., 2003, 'Reality or perception? The effect of actual and perceived performance on satisfaction and behavioural intention', Journal of Service Research 5(4), 292-302.

Busse, C. \& Wallenburg, C., 2011, 'Innovation management of logistics service providers: Foundations, review, and research agenda', International Journal of Physical Distribution \& Logistics Management 41(2), 187-218.

Bustinza, O., Parry, G. \& Vendrell-Herrero, F., 2013, 'Supply and demand chain management: The effect of adding services to product offerings', Supply Chain Management: An International Journal 18(6), 618-629.

Calabrese, A. \& Scoglio, F., 2012, 'Reframing the past: A new approach in service quality assessment', Total Quality Management \& Business Excellence 23(11-12) quality assess $1329-1343$.

Chandler, J. \& Lusch, R., 2015, 'Service systems a broadened framework and research agenda on value propositions, engagement, and service experience', Journal of Service Research 18(1), 6-22.

Chen, C., Yan, S. \& Tseng, C., 2010, 'Inter-city bus scheduling for allied carriers', Transportmetrica 6(3), 161-185.

Choi, J., Coughlin, J. \& D’Ambrosio, L., 2012, 'Travel time and subjective well-being', Paper presented at the 92nd Annual Meeting of the Transportation Research Board, Washington, DC.

Church, A., 1997, 'Do you see what I see? An exploration of congruence in ratings from multiple perspectives', Journal of Applied Social Psychology 27(11), 983-1020.

Connelly, B., Ketchen, D. \& Hult, G., 2013, 'Global supply chain management: Toward a theoretically driven research agenda', Global Strategy Journal 3(3), 227-243.

Conway, T., Dalton, C., Loo, J. \& Benakoun, L., 2008, 'Developing ecological footprint scenarios on university campuses: A case study of the University of Toronto at Mississauga', International Journal of Sustainability in Higher Education 9(1), 4-20.

Correia, G. \& Antunes, A., 2012, 'Optimization approach to depot location and trip selection in one-way carsharing systems', Transportation Research Part E: Logistics and Transportation Review 48(1), 233-247.

Cronbach, L., 1951, 'Coefficient alpha and the internal structure of tests', Psychometrika 16(3), 297-234.

Dagger, T. \& Sweeney, J., 2007, 'Service quality attribute weights: How do novice and longer-term customers construct service quality perceptions?', Journal of Service longer-term customers
Research 10(1), 22-42.

Daugherty, P., 2011, 'Review of logistics and supply chain relationship literature and suggested research agenda', International Journal of Physical Distribution \& Logistics Management 41(1), 16-31.

Daugherty, P., Chen, H. \& Ferrin, B., 2011, 'Organizational structure and logistics service innovation', International Journal of Logistics Management 22(1), 26-51.

Defee, C., Williams, B., Randall, W. \& Thomas, R., 2010, 'An inventory of theory in logistics and SCM research', International Journal of Logistics Management 21(3), 404-489.

De Ona, J. \& De Ona, R., 2015, 'Quality of service in public transport based on customer satisfaction surveys: A review and assessment of methodological approaches', Transportation Science 49(3), 605-622.
De Ona, J., De Ona, R., Eboli, L. \& Mazzulla, G., 2013, 'Perceived service quality in bus transit service: A structural equation approach', Transport Policy 29, 219-226.

Dell'Olio, L., Ibeas, A. \& Cecin, P., 2010, 'Modelling user perception of bus transit quality', Transport Policy 17, 388-397.

De Vos, J., Schwanen, T., Van Acker, V. \& Witlox, F., 2013, 'Travel and subjective wellbeing: A focus on findings, methods and future research needs', Transport Reviews 33(4), 421-442.

Diana, M., 2012, 'Measuring the satisfaction of multimodal travellers for local transit services in different urban contexts', Transportation Research Part A: Policy and Practice 46(1), 1-11.

Eboli, L. \& Mazzulla, G., 2007, 'Service quality attributes affecting customer satisfaction for bus transit', Journal of Public Transportation 10(3), 21-34.

Eboli, L. \& Mazzulla, G., 2011, 'A methodology for evaluating transit service quality based on subjective and objective measures from the passenger's point of view', Transport Policy 18(1), 172-181.

Eboli, L., Mazzulla, G. \& Salandria, A., 2013, 'Sustainable mobility at a university campus: Walking preferences and the use of electric minibus', International Journal of Transportation 1(1), 21-34.

Ellinger, A., Keller, S. \& Baş, A., 2010, 'The empowerment of frontline service staff in 3PL companies', Journal of Business Logistics 31(1), 79-98.

Engel, J. \& Blackwell, R., 1982, Consumer behaviour, Hole, Rinehard and Winston, New York, NY.

Eriksson, L., Friman, M. \& Garling, T., 2013, 'Perceived attributes of bus and car mediating satisfaction with the work commute', Transportation Research Part A: Policy and Practice 47, 87-96.

Ettema, D., Gärling, T., Eriksson, L., Friman, M., Olsson, L. \& Fujii, S., 2011, 'Satisfaction with travel and subjective well-being: Development and test of a measurement tool', Transportation Research Part F: Traffic Psychology and Behaviour 14(3), 167-75.

Farzaneh, M., Lee, J., Ramani, T., Higgins, L. \& Zietsman, J., 2009, 'Toward a green campus: A transportation strategy for Texas A\&M University', Southwest Region campus: A transportation strategy for Texas A\&M University', Southwest Region University Transporta
University System.

Fellesson, M. \& Friman, M., 2012, 'Perceived satisfaction with public transport service in nine European cities', Journal of the Transportation Research Forum 47(3) 93-103.

Fernandez, R., 2010, 'Modelling public transport stops by microscopic simulation', Transportation Research Part C 18(6), 856-868.

Field, A., 1999, 'The college student market segment: A comparative study of trave behaviours of international and domestic students at a Southeastern University', Journal of Travel Research 37(4), 375-381.

Fisk, G. \& Haase, S., 2011, 'The relationship between the objective identification threshold and priming effects does not provide a definitive boundary between conscious and unconscious perceptual processes', Consciousness and Cognition 20(4), 1221-1231.

Gatersleben, B. \& Uzzell, D., 2007, 'The journey to work: Exploring commuter mood among driver, cyclists, walkers and users of public transport', Environment and Behaviour 39, 416-431.

Golder, P., Mitra, D. \& Moorman, C., 2012, 'What is quality? An integrative framework of processes and states', Journal of Marketing 76(4), 1-23.

Gonzalez-Loureiro, M., Dabic, M. \& Kiessling, T., 2015, 'Supply chain management as the key to a firm's strategy in the global marketplace: Trends and research agenda', International.

Grawe, S., 2009, 'Logistics innovation: A literature-based conceptual framework', International Journal of Logistics Management 20(3), 360-177.

Grawe, S., Autry, C. \& Daugherty, P., 2014, 'Organizational implants and logistics service innovation', Transportation Journal 53(2), 180-210.

Gu, W., Li, L., Cassidy, M. \& Griswold, J., 2011, 'On the capacity of isolated, curbside bus stops', Transportation Research Part B: Methodological 45(4), 714-723.

Hensher, D., 2014, 'The relationship between bus contract costs, user perceived service quality and performance assessment', International Journal of Sustainable Transportation 8(1), 5-27.

Hensher, D., Stopher, P. \& Bullock, P., 2003, 'Service quality- developing a service quality index in the provision of commercial bus contracts', Transportation Research Part A: Policy and Practice 37(6), 499-517.

Higher Education Statistics Agency, 2010, Students and qualifiers data base, Students by institution, viewed 04 August 2011, from http://www.hesa.ac.uk/index.php/ content/view/1973/239/

Hsu, W., 2013, 'Improving the service operations of container terminals', International Journal of Logistics Management 24(1), 101-116.

Hu, K. \& Jen, W., 2006, 'Passengers' perceived service quality of city buses in Taipei Scale development and measurement', Transportation Review 26(5), 645-662.

Hu, L-T. \& Bentler, P.M., 1999, 'Cutoff criteria for fit indexes in covariance structure analysis: Conventional criteria versus new alternatives', Structural Equation Modelling 6, 1-55.

Jain, S., Aggarwal, P., Kumar, P., Singhal, S. \& Sharma, P., 2014, 'Identifying public preferences using multi-criteria decision making for assessing the shift of urban commuters from private to public transport: A case study of Delhi', Transportation Research Part F: Traffic Psychology and Behaviour 24, 60-70.

Joreskog, K. \& Sorbom, D., 1993, LISREL 8: Structural equation modelling with the SIMPLIS command language, Scientific Software International. 
Kahkonen, A., Lintukangas, K. \& Hallikas, J., 2015, 'Buyer's dependence in value creating supplier relationships', Supply Chain Management: An International Journal 20(2), 151-162.

Kelly, J., 2005, 'The dilemma of the unsatisfied customer in a market model of public administration', Public Administration Review 65(1), 76-84.

Kepaptsoglou, K. \& Karlaftis, M., 2009, 'The bus bridging problem in metro operations: Conceptual framework, models \& algorithms', Public Transport 1(4) 275-297.

Likert, R., 1932, 'A technique for the measurement of attitudes', Archive of Psychology 22(140), 1-55.

Limanond, T., Butsingkorn, T. \& Chermkhunthod, C., 2011, 'Travel behaviour of university students who live on campus: A case study of a rural university in Asia', Transport Policy 18(1) 163-71.

Lin, Y., Pekkarinen, S. \& Ma, S., 2015, 'Service-dominant logic for managing the logistics-manufacturing interface: A case study', International Journal of Logistics Management 26(1), 195-214.

Marshall, A. \& Ojiako, U., 2010, 'From the myth of Prometheus to strategic resilience: Two cognitive paradigms linking risk and innovation', Prometheus 28(4), 343-360.

McLennan, P. \& Bennetts, M., 2003, 'The journey to work: A descriptive UK case study', Facilities 21(7/8), 180-187.

Morris, E., 2013, 'Access and outcomes: Transportation, location and subjective wellbeing', Paper presented at the 92nd Annual Meeting of the Transportation Research Board, Washington, DC.

Morris, E. \& Guerra, E., 2014, 'Mood and mode: Does how we travel affect how we feel?', Transportation 42(1), 25-43.

Morris, M., Ison, S. \& Enoch, M., 2005, 'The role of UK local authorities in promoting the bus', Journal of Public Transportation 8(5), 25-40.

Nunnally, J., 1967, Psychometric theory, McGraw-Hill.

Nunnally, J., 1978, Psychometric theory, McGraw-Hill.

Nyffenegger, B., Krohmer, H., Hoyer, W. \& Malaer, L., 2014, 'Service brand relationship quality hot or cold?', Journal of Service Research. http://dx.doi. org/1094670514547580

Olhager, J., Pashaei, S. \& Sternberg, H., 2015, 'Design of global production and distribution networks: A literature review and research agenda', International Journal of Physical Distribution \& Logistics Management 45(1/2), 138-158.

Oliver, R., 1981, 'Measurement and evaluation of satisfaction processes in retail settings', Journal of Retailing 57(3), 25-48.

Olsson, L., Friman, M., Pareigis, J. \& Edvardsson, B., 2012, 'Measuring service experience: Applying the satisfaction with travel scale in public transport', Journal of Retailing and Consumer Services 19(4), 413-418.

Ostrom, A., Parasuraman, A., Bowen, D., Patrício, L., Voss, C. \& Lemon, K., 2015 'Service research priorities in a rapidly changing context', Journal of Service Research 18(2), 127-159.

Paez, A. \& Whalen, K., 2010, 'Enjoyment of commute: A comparison of different transportation modes', Transportation Research Part A: Policy and Practice 44(7), 537-549.

Pallant, J., 2010, SPSS survival manual, 4th edn., Open University Press, McGraw-Hill.

Parasuraman, A., Zeithaml, V. \& Malhotra, A., 2005, 'ES-QUAL a multiple-item scale for assessing electronic service quality', Journal of Service Research 7(3), 213-233.

Park, J. \& Kim, B., 2010, 'The school bus routing problem: A review', European Journal of Operational Research 202(2), 311-319.

Pedrosa, A., Blazevic, V. \& Jasmand, C., 2015, 'Logistics innovation development: A micro-level perspective', International Journal of Physical Distribution \& Logistics Management 45(4), viewed 30 April 2015, from http://www.emeraldinsight.com/ doi/pdfplus/10.1108/IJPDLM-12-2014-0289

Politis, I., Papaioannou, P., Basbas, S. \& Dimitriadis, N., 2010, 'Evaluation of a bus passenger information system from the users' point of view in the city of Thessaloniki, Greece', Research in Transportation Economics 29, 249-255.

Salicru, M., Fleurent, C. \& Armengol, J., 2011, 'Timetable-based operation in urban transport: Run-time optimisation and improvements in the operating process', Transportation Research Part A: Policy and Practice 45(8), 721-740.
Sengupta, A., Balaji, M. \& Krishnan, B., 2015, 'How customers cope with service failure? A study of brand reputation and customer satisfaction', Journal of Business Research 68(3), 665-674.

Shah, R. \& Goldstein, S., 2006, 'Use of structural equation modelling in operations management research: Looking back and forward', Journal of Operations Management 24(2), 148-169.

Sharma, N., 2003, 'The role of pure and quasi-moderators in services: An empirical investigation of ongoing customer-service-provider relationships', Journal of Retailing and Consumer Services 10(4), 253-262.

Sheth, C., Triantis, K. \& Teodorovic, D., 2007, 'Performance evaluation of bus routes: A provider and passenger', Transportation Research Part E: Logistics and Transportation Review 43(4), 453-478.

Shiftan, Y., Outwater, M. \& Zhou, Y., 2008, 'Transit market research using structural equation modelling and attitudinal market segmentation', Transport Policy 15, 186-195.

Slater, S., 1997, 'Developing a customer value-based theory of the firm', Journal of the Academy of Marketing Science 25(2), 162-167.

Stradling, S., Carreno, M., Rye, T. \& Noble, A., 2007, 'Passenger perceptions and the ideal urban bus journey experience', Transport Policy 14(4), 283-292.

Su, S., Ke, J. \& Cui, L., 2014, 'Assessing the innovation competence of a third-party logistics service provider: A survey approach', Journal of Management Policy and Practice 15(4), 64-79.

Sureshchandar, G., Rajendran, C. \& Anantharaman, R., 2002, 'The relationship between service quality and customer satisfaction - a factor specific approach', Journal of Services Marketing 16(4), 363-379.

Tang, L. \& Thakuriah, P., 2012, 'Ridership effects of real-time bus information system: A case study in the city of Chicago', Transportation Research Part C: Emerging Technologies 22, 146-161.

Tokar, T., 2010, 'Behavioural research in logistics and supply chain management', International Journal of Logistics Management 21(1), 89-103.

Ubillosa, J. \& Sainzb, A., 2004, 'The influence of quality and price on the demand for urban transport: The case of university students', Transportation Research Part A: Policy and Practice 38(8), 607-614.

Van Oudheusden, D., Ranjithan, S. \& Singh, K., 1987, 'The design of bus route systems - An interactive location-allocation approach', Transportation 14, 253-270.

Van Vugt, M., Van Lange, P. \& Meertens, R., 1996, 'Commuting by car or public transportation? A social dilemma analysis of travel mode judgements', European Journal of Social Psychology 26(3), 373-395.

Wall, G., Felstead, T., Richards, A. \& McDonald, M., 2008, 'Cleaner vehicle buses in Winchester', Transport Policy 15, 55-68.

Wall, G. \& McDonald, M., 2007, 'Improving bus service quality and information in Winchester', Transport Policy 14, 165-179.

Weele, A. \& Raaij, E., 2014, 'The future of purchasing and supply management research: About relevance and rigor', Journal of Supply Chain Management 50(1), 56-72.

Weinstein, A., 2000, 'Customer satisfaction among transit riders: How customers rank the relative importance of various service attributes', Transportation Research Record: Journal of the Transportation Research Board 1735(1), 123-132.

White, P., 2010, 'Reforming public transport throughout the world: The conflict between competition policy and the wider role of the local bus industry in Britain', Research in Transportation Economics 29(1), 152-158.

Wirasinghe, S. \& Vandebona, U., 2011, 'Route layout analysis for express buses', Transportation Research Part C: Emerging Technologies 19(2), 374-385.

Yang, H., Kong, H. \& Meng, Q., 2001, 'Value-of-time distributions and competitive bus services', Transportation Research Part E: Logistics and Transportation Review 37(6), 411-424.

Yazdanparast, A., Manuj, I. \& Swartz, S., 2010, 'Co-creating logistics value: A servicedominant logic perspective', International Journal of Logistics Management 21(3), 375-403.

Zayer, L., Otnes, C. \& Fischer, E., 2014, 'The nature and implications of consumers' experiential framings of failure in high-risk service contexts', Journal of Service Research, In Press, http://dx.doi.org/1094670514559187 